\title{
Pelayanan Hak Mengetahui Oleh Surat Kabar Kompas dan Majalah Tempo
}

\author{
Ana Nadhya Abrar \\ Program Studi Ilmu Komuniasi Universitas Gajah Mada Yogyakarta \\ Email: ana.abrar@gmail.com
}

\begin{abstract}
Frequency of corruption news lately experienced a significant improvement. Various news media and broadcast media appear ferocious in reporting corruption cases. All the media have the moral courage to reveal what actually happened on corruptors, ranging from members of Parliament, deputy ministers, governors, senior police, until echelons in the bureaucracy. The result is relatively good. Audience could follow it properly. Starting from here, a problem arises, whether such reporting is intended to fulfill the right to know of the audience? This study wanted to find answers. Therefore, the following study examined headlines about corruption were reported by Kompas newspaper and main reports by Tempo magazine during June and July 2013. However, in the period just one headline of corruption news reported by Kompas newspaper, namely the issue of July 27, 2013 and one main report of corruption news reported by Tempo magazine, namely the issue of July 15 to 21, 2013, titled "Perempuan tudy Misterius Hambalang" ("Mysterious Woman from Hambalang"). The study used a qualitative content analysis answered an important question, namely: How is the service of the right to know on broadcasting corruption news committed by Kompas newspaper and Tempo magazine during June and July 2013? Data were analyzed by using cultural perspective that could lead to the conclusion: the right to know which was serving by Kompas newspaper and Tempo magazines was good.
\end{abstract}

Keywords: Right to know, main report, main news, corruption news cultural perspective

\begin{abstract}
Abstrak
Frekuensi berita korupsi akhir-akhir ini mengalami peningkatan yang sangat berarti. Berbagai media pers dan media penyiaran tampil garang dalam memberitakan kasus korupsi. Semua media tersebut memiliki keberanian moral untuk mengungkapkan apa yang sesungguhnya terjadi pada koruptor, mulai dari anggota DPR, wakil menteri, gubernur, perwira tinggi polisi, hingga pejabat eselon di birokrasi. Hasilnya relatif bagus. Khalayak bisa mengikuti kisah korupsi dengan baik. Bertolak dari sini, timbul masalah, apakah pemberitaan semacam itu memang diniatkan untuk memenuhi hak mengetahui yang dimiliki khalayak? Penelitian ini ingin memperoleh jawabannya. Untuk itu, penelitian berikut mengkaji semua laporan utama dan berita utama tentang korupsi yang dilaporkan majalah Tempo dan surat kabar Kompas selama bulan Juni dan Juli 2013. Namun, dalam periode tersebut hanya satu berita utama (headline) Kompas yang melaporkan berita korupsi, yakni edisi 27 Juli 2013 dan satu pula laporan utama majalah Tempo yang melaporkan berita korupsi, yaitu edisi 15-21 Juli 2013, berjudul "Perempuan Misterius Hambalang”. Dalam pelaksanaannya, penelitian ini menggunakan analisis isi kualitatif yang menjawab sebuah pertanyaan penelitian penting, yaitu:
\end{abstract}


Bagaimana pelayanan hak mengetahui pada penyiaran berita korupsi yang dilakukan surat kabar Kompas dan majalah Tempo selama Juni dan Juli 2013? Data yang diperoleh dianalisis mengggunakan perspektif kebudayaan sehingga menghasilkan kesimpulan: pelayanan hak mengetahui yang dilakukan surat kabar Kompas dan majalah Tempo sudah bagus.

Kata Kunci: hak mengetahui, laporan utama, berita utama, berita korupsi, perspektif kebudayaan.

\section{Pendahuluan}

Pada bulan Mei 1998, mahasiswa menduduki gedung Dewan Perwakilan Rakyat (DPR). Mereka menginjakkan kaki di dua atap bundar beton gedung yang menjadi salah satu simbol demokrasi di Indonesia. Mereka meneriakkan reformasi dengan titik keringat dan air mata. Mereka tidak peduli dengan nasib yang akan menimpa mereka. Hal yang mereka inginkan hanya reformasi.

Apakah mereka mengerti persis apa yang mereka inginkan? Apakah mereka benar-benar mengerti makna reformasi? Bisa jadi reformasi itu hanya keinginan para pakar seperti Amien Rais atau hanya kebutuhan para politisi. Hal yang jelas gerakan mahasiswa itu berujung: Pemerintahan Soeharto tumbang setelah mendominasi kehidupan sosial-politik Indonesia selama 32 tahun lebih.

Pada tahun 2013, lima belas tahun setelah reformasi, apakah reformasi itu sudah berjalan dengan benar? Apakah reformasi tersebut sudah mengantarkan masyarakat kepada tingkat kehidupan yang sejahtera, adil, dan makmur? Tidak mudah menjawab pertanyaan ini tanpa penelitian yang saksama. Jika dilihat dari sisi civil rights dan civil liberties, reformasi sudah berhasil (Parlementaria edisi 103, 2013).

Namun, apakah itu berarti bahwa Indonesia sudah memiliki jiwa demokrasi yang sesungguhnya? Banyak yang sepakat bahwa demokrasi di Indonesia masih belum memiliki roh demokrasi yang sebenarnya. Apa yang terjadi masih dalam taraf demokrasi prosedural. Sampai di sini agaknya perlu dipertanyakan soal pelayanan hak mengetahui yang dimiliki masyarakat. Tegasnya, apakah reformasi sudah mendorong media pers untuk melayani hak mengetahui yang dimiliki masyarakat?

Sejauh yang terungkap dalam latar belakang di atas, masalah pokok yang dimiliki Indonesia sekarang adalah negara terperangkap dalam prosedur. Indonesia memiliki semuakomisi yang diperlukan untuk checks and balances antara pemerintah dan rakyat. Indonesia juga mengikuti segala prosedur yang menyebabkan Indonesia disebut sebagai negara demokrasi. Kenyataan ini, diikuti pula oleh media pers. Artinya, media pers, secara prosedural, memang berusaha melayani hak mengetahui yang dimiliki masyarakat. Tetapi, media pers tidak memiliki roh tentang pemenuhan itu.

Untuk memastikannya, perlu dilihat penampilan media pers selama bulan Juni dan Juli 2013. Pemilihan waktu ini didasari oleh kenyataan bahwa peringatan 15 tahun reformasi berlangsung bulan Mei 2013. Dengan begitu, 15 tahun pasca reformasi terhitung sejak Juni 2013. Untuk menambah rentang waktu pasca reformasi, dipilih bulan Juni dan Juli 2013.

Bertolak dari masalah di atas, patut disusun sebuah pertanyaan penelitian berikut: Bagaimana kondisi pelayanan hak mengetahui terkait berita korupsi yang dilakukan Majalah Berita Mingguan (MBM) Tempo dan Suratkabar Harian (SKH) Kompas selama Juni dan Juli 2013 ?

\section{Metode Penelitian}

Metode penelitian yang digunakan dalam penelitian ini adalah analisis isi kualitatif. Artinya, peneliti mencatat semua fakta: (i) yang menjawab pertanyaan $5 \mathrm{~W}+1 \mathrm{H}$ untuk setiap berita, dan (ii) Setelah itu, peneliti melihat 
konsep keadilan dan hasrat popularitas yang terdapat di dalamnya. Kemudian, peneliti menginterpretasikan hasil temuan tersebut agar bisa menjawab pertanyaan penelitian. Data yang terkumpul dianalisis menggunakan perspektif kebudayaan yaitu kebudayaan yang progresif, seperti diperkenalkan oleh Jakob Oetama (2009:11), yang antara lain ditandai oleh orientasi masa depan dan hidup yang lebih baik.

Objek utama dalam penelitian ini adalah laporan utama MBM Tempo dan Berita Utama SKH Kompas yang berkaitan dengan masalah korupsi. Ada tiga alasan kenapa berita korupsi, yakni, pertama, korupsi merupakan kejahatan yang paling tidak bisa ditolerir. Kedua, korupsi menghambat tugas negara menyejahterakan masyarakat. Ketiga, korupsi memperburuk citra bangsa Indonesia di dunia internasional (Respon, 1 Juli 2003).

Semua laporan utama dan berita utama tentang korupsi yang dilaporkan MBM Tempo dan SKH Kompas selama bulan Juni dan Juli 2013 menjadi objek utama penelitian ini. Namun, dalam periode tersebut hanya satu berita utama (headline) Kompas yang melaporkan berita korupsi, yakni edisi 27 Juli 2013.

\section{Hasil dan Pembahasan}

Inilah beritanya:

\section{Diyakini Hanya Perantara: \\ KPK Tetapkan Mario Bernardo dan Djodi Supratman sebagai Tersangka}

JAKARTA, KOMPAS - Pengacara pada kantor hukum Hotma Sitompoel \& Associates, Mario C Bernardo, dan pegawai Mahkamah Agung, Djodi Supratman, diyakini menjadi perantara yang mengurus perkara penipuan dengan terdakwa Hutomo Wijaya Ongowarsito, yang kini tengah kasasi di MA.

Pada Jumat (26/7), Komisi Pemberantasan Korupsi menetapkan Mario dan Djodi sebagai tersangka seusai penangkapan yang dilakukan Kamis lalu.

"Setelah melakukan pemeriksaan secara intensif, penyidik KPK menemukan dua alat bukti yang cukup, yang kemudian menyimpulkan bahwa telah terjadi tindak pidana korupsi yang dilakukan oleh MCB (Mario C Bernardo). Seorang lawyer ditetapkan sebagai tersangka," kata Juru Bicara KPK Johan Budi SP.

Menanggapi hal itu, Tommy Sihotang, yang juga penasihat hukum Mario C Bernardo, menyatakan, kasus tangkap tangan kedua orang tersebut tidak ada kaitan dengan kantor Hotma Sitompoel. Hal itu dibuktikan, misalnya, tak ada kop surat atau bukti lain menyangkut kantor pengacara Hotma Sitompoel.

Mario diduga melanggar Pasal 5 Ayat 1 Huruf a atau Pasal 13 Undang-Undang Nomor 31 Tahun 1999 sebagaimana diubah dengan UU No 20/2001 tentang Pemberantasan Tindak Pidana Korupsi juncto Pasal 55 Ayat 1 Kesatu KUHP. "Kasusnya adalah dugaan tindak pidana korupsi dalam kaitan memberi atau menjanjikan kepada pegawai negeri atau penyelenggara negara, terkait dengan pengurusan kasasi tindak pidana penipuan atas nama terdakwa HWO (Hutomo Wijaya Ongowarsito) di MA," ujar Johan.

Terhadap Djodi, KPK menyangka yang bersangkutan melanggar Pasal 5 Ayat 2 atau Pasal 11 UU No 31/1999 sebagaimana diubah dengan UU No 20/2001 tentang 
Pemberantasan Tindak Pidana Korupsi. "Bersamaan dengan itu juga disita barang bukti berupa uang Rp 50 juta dan sekitar Rp 78 juta. Jadi, sekitar Rp 128 juta ditemukan di tas yang dibawa DS (Djodi Supratman) dan juga di rumah DS," katanya.

Mario dan Djodi diduga hanya sebagai perantara. Menurut Johan, KPK terus mengembangkan kasus ini. "Ini kami kembangkan, apakah ada pihak lain yang terlibat," katanya. Djodi adalah pegawai bagian pendidikan dan latihan (pusdiklat) di MA. "Meski dia enggak menangani (perkara), kan bisa mengurus. Konteks pemberian ini berkaitan dengan pengurusan kasus kasasi pidana penipuan atas nama terdakwa HWO," tutur Johan.

Ia menambahkan, Djodi diduga menerima pemberian itu dalam rangka mengurus proses kasasi perkara tersebut. "Pas tangkap tangan, itu sudah pemberian kedua. Sebelumnya sudah ada pemberian yang diterima DS," kata Johan.

Namun, Hakim Agung Gayus Lumbuun mengaku tidak mengenal Djodi. Ia akan mengecek berkas kasasi yang terkait dengan upaya pemberian suap dari Mario kepada Djodi.

Berdasarkan data di situs MA, perkara Hutomo ditangani tiga hakim agung, yaitu Gayus Lumbuun sebagai Pembaca I, Andi Ayyub sebagai Pembaca II, dan Zaharuddin Utama sebagai Pembaca III sekaligus ketua majelis kasasi. Majelis kasasi dibantu panitera pengganti Ikhsan Fathoni. Perkara tersebut diajukan jaksa melalui Pengadilan Negeri Jakarta Selatan pada 9 April lalu. Perkara itu kemudian didistribusikan kepada majelis hakim pada 27 Mei.

Ditanya sejauh mana penanganan perkara Hutomo, Gayus Lumbuun mengatakan baru akan mengecek Senin mendatang. "Saya belum jelas permasalahannya, saya tidak kenal DS," ujarnya.

Kepala Biro Hukum dan Humas MA Ridwan Mansyur mengungkapkan, pihaknya akan memberhentikan Djodi setelah tertangkap KPK. Djodi adalah petugas satpam MA sejak 1986 hingga 2009, kemudian diangkat menjadi pegawai dan ditempatkan di Pusdiklat MA di Megamendung, Bogor, Jawa Barat.

Ridwan menyerahkan permasalahan itu kepada KPK. Menurut Ridwan, pihaknya siap bekerja sama dengan KPK jika KPK akan mengembangkan penyelidikan kasus tersebut.

\section{Reformasi Gagal}

Dengan adanya kasus ini, setelah masa reformasi, bisa dikatakan reformasi birokrasi penegak hukum mengalami kegagalan. Hal itu juga tecermin dari banyaknya kasus yang menimpa hakim, panitera, dan petugas MA tersebut.

"Tempo hari, ada hakim ditangkap di Bandung. Lalu, ada kasus penangkapan KPK yang terkait pegawai MA. Ini sangat memprihatinkan karena benteng terakhir keadilan itu justru di MA. Bagaimana hukum kita jika pegawai di MA masih terima-terima 
uang?” kata Ketua Umum Persatuan Advokat Indonesia (Peradi) Frans H Winarta.

Terkait dengan beberapa kejadian itu, reformasi birokrasi penegak hukum mutlak diperlukan. Hal tersebut terutama agar birokrasi di Indonesia menjadi lebih bersih, jujur, efisien, dan produktif. "Perbaikannya harus multifaktor dan dikerjakan secara serius; mulai dari perekrutan, sistem penggajian, hingga perbaikan gedung pengadilan," katanya. "Reformasi dari birokrasi penegak hukum menjadi salah satu tugas terberat dari pemerintah mendatang. Apalagi, setelah belasan tahun reformasi, ternyata hukum kita tidak juga menjadi lebih baik," ujar Frans.

Terkait dengan penangkapan pada Kamis lalu yang melibatkan advokat, Ketua Bidang Hukum Indonesia Corruption Watch (ICW) Emerson Yuntho berharap pengusutan KPK jangan berhenti pada Mario dan Djodi.

Dalam catatan ICW, ada enam advokat ditangkap dan divonis terkait dengan dugaan suap. Advokat Haposan Hutagalung, misalnya, berdasarkan data ICW, atas keterlibatan dalam mafia kasus Gayus Tambunan dan suap kepada Komisaris Jenderal Susno Duadji, divonis MA selama 12 tahun penjara ditambah denda Rp 500 juta.

Menurut Tommy Sihotang, pemberitaan terkait dengan penangkapan Mario dan DS ini juga tak terkait kasus Inspektur Jenderal Djoko Susilo dalam perkara korupsi simulasi berkendara. Inisial DS itu bukan inisial Djoko Susilo. "Tak ada kaitannya dengan kasus Djoko Susilo. Itu terkait kasus yang sedang berjalan di MA," katanya.

Namun, Tommy tak mau menyebutkan kasus apa yang dimaksud. "Untuk etisnya, biar KPK dulu yang menyampaikan. Saya tak tahu kasusnya apa, jangan-jangan tidak ada kasus, bisa saja teman lama yang memberi uang," katanya.Sebelumnya, Hotma Sitompoel juga mengatakan tidak mengetahui kasus yang membuat Mario ditangkap. Namun, dia membenarkan bahwa Mario adalah keponakannya. (BIL/ANA/RYO/ AMR).

Dalam periode yang sama, MBM Tempo hanya sekali melaporkan laporan utama tentang korupsi, yaitu edisi 15-21 Juli 2013. Laporan

utama tersebut berjudul "Perempuan Misterius Hambalang."

Berikut berita selengkapnya:

\section{Kode "F" di Tahap Kedua Korupsi Hambalang}

Dana korupsi proyek Hambalang ternyata mengalir ke segala penjuru. Dari pejabat Kementerian Olahraga hingga orang yang dekat dengan pusat kekuasaan. Pelicin proyek setelah kontrak diteken.

Dua Ani di Kementerian Keuangan menjadi pembicaraan lima orang yang meriung di Senayan Cafe, Hotel Atlet Century Park, pada awal Juni 2010: "Ani Besar" dan "Ani Kecil". Ani Besar untuk menyebut Menteri Keuangan Sri Mulyani Indrawati, yang waktu itu baru saja digantikan Agus Martowardojo. Adapun Ani Kecil julukan untuk Wakil Menteri Keuangan Anny Ratnawati, yang masih merangkap menjadi Direktur Jenderal Anggaran. 
Kelima orang itu-Widodo Wisnu Sayoko, Arif "Gundul", Lisa Lukitawati Isa, Muhammad Arifin, dan Ida Bagus- membahas rencana pengajuan kontrak tahun jamak proyek Pusat Pendidikan dan Pelatihan Sekolah Olahraga Nasional di Bukit Hambalang, Bogor, ke Kementerian Keuangan. Mereka bukan pejabat Kementerian Pemuda dan Olahraga, tapi bergaul sangat akrab dengan para petinggi kementerian pemilik proyek itu.

Desain dan perhitungan biaya sudah rampung disusun Kementerian Pemuda dan Olahraga. Yang diperlukan tinggal persetujuan kontrak tahun jamak dari Kementerian Keuangan-syarat dimulainya pembangunan Hambalang. Kontrak tahun jamak mengikat anggaran untuk proyek yang pelaksanannya lebih dari satu tahun. Hambalang semula direncanakan dimulai pada akhir 2010 dan selesai akhir 2012.

Persoalannya, belum tentu Kementerian Keuangan segera menyetujui permohonan yang diajukan. Untuk mempercepat prosesnya, Kementerian Olahraga menggunakan jalur belakang. "Itu gampang. Nanti bisa lewat Ani Kecil,"kata Arif "Gundul" seperti ditirukan sumber Tempo. Arif datang ke Senayan Cafe bersama Widodo. Keduanya optimistis persetujuan kontrak bisa lekas turun karena ada seseorang di atas mereka: Syivia Sholehah alias Ibu Pur.

Perempuan paruh baya itu disebut sebagai orang dekat Ibu Negara, Ani Yudhoyono. Bermodal kekuatan itu, Arif dan Widodo yakin Sylvia bisa mempengaruhi Anny Ratnawati. Tak ada makan siang gratis. Berjanji membantu pengurusan kontrak di Kementerian Keuangan, Arif dan Widodo meminta imbalan Rp 5 miliar.

Widodo adalah kerabat Sylvia. Ia bersahabat dengan Arif. Keduanya datang ke Senayan Cafe sebagai tamu, sebagaimana Muhammad Arifin, Direktur PT Methapora Solusi Global, perusahaan konsultan perencanaan konstruksi, dan Ida Bagus, anggota staf pemasaran PT Adhi Karya. Sahibulhajatnya Lisa Lukitawati, pengusaha peralatan olahraga yang ditunjuk Sekretaris Kementerian Olahraga Wafid Muharam sebagai anggota tim perencana proyek Hambalang. Lisa mengundang tetamu atas instruksi Wafid. Ditemui pada Kamis pekan lalu, Lisa hanya menggelengkan kepala ketika dimintai konfirmasi. Ditanya apakah kenal dengan Sylvia, Widodo, dan Arif, ia menjawab, "Tanyakan kepada Pak Wafid, deh."

Setelah urusan tadi beres, Wafid Muharam mengajukan kontrak tahun jamak ke Kementerian Keuangan pada 28 Juni 2010. Dalam suratnya, Wafid menulis konstruksi Hambalang membutuhkan biaya Rp 1,175 triliun. Ditambah anggaran peralatan yang kelak mengisi bangunan, bujet totalnya $\mathrm{Rp} 2,57$ triliun.

Sampai di kantor Kementerian Keuangan di Lapangan Banteng, surat Wafid Muharam tertanggal 28 Juni 2010 dibalas Direktur Jenderal Anggaran Anny Ratnawati pada 13 Juli. Anny meminta Kementerian Olahraga melengkapi persyaratan, antara lain rekomendasi kelayakan kontrak tahun jamak dari Kementerian Pekerjaan Umum. 
Setelah sekian kali berkirim surat, pada 16 November 2010, Wafid meminta dispensasi batas waktu revisi pengajuan rencana kerja anggaran kementerian/lembaga 2011 yang di dalamnya termaktub anggaran Hambalang. Semestinya revisi diajukan sebelum 15 Oktober. Dalam surat itu juga Wafid menjelaskan soal rekomendasi Kementerian Pekerjaan Umum tapi tak melampirkan dokumen, salah satunya, analisis komponen biaya proyek Hambalang.

Pada 22 November, Wafid meminta analisis komponen biaya Hambalang dari Kementerian Pekerjaan Umum. Menurut sumber, di sinilah jasa Sylvia alias Ibu Pur mulai ampuh. Pengurusan kontrak tahun jamak ke Kementerian Keuangan dan Kementerian Pekerjaan Umum memang satu paket. Berbeda dengan pengurusan surat sebelumnya yang memakan waktu lama, kali ini dokumen yang diminta Wafid langsung beres keesokan harinya.

Di Lapangan Banteng, proses persetujuan anggaran yang tadinya lambat juga mendadak dikebut. Belum begitu jelas bagaimana Sylvia, Widodo, dan Arif mencampuri proses di Kementerian Keuangan. Tapi, begitu surat permohonan dispensasi revisi pengajuan rencana anggaran dari Wafid sampai ke menjanya pada 22 November, Anny langsung mendisposisikan itu secara berjenjang ke direktur hingga kepala subdirektorat.

Empat hari kemudian, kepada subdirektorat menyusun nota dinas hasil penelaahan terhadap dokumen persyaratan yang dilampirkan Wafid. Konsep nota dinas menyebut persyaratan terpenuhi sehingga revisi pengajuan anggaran tahun jamak bisa disetujui. Sampai di tangan Anny Ratnawati pada 29 November, isi nota dinas tak berubah.

Pada hari itu juga, Anny membuat nota dinas bernomor ND-1034/AG/2010 perihal persetujuan kontrak tahun jamak kepada Menteri Keuangan. Menjawab nota dinas itu, Menteri Agus Martowardojo pada 1 Desember memberikan disposisi kepada Anny. "Selesaikan,"demikian disposisinya.

Anny kemudian menerbitkan surat bernomor s-3576/AG/2010 tertanggal 6 Desember 2010 yang menyetujui revisi rencana anggaran Kementerian Olahraga, termasuk pembiayaan Hambalang. Mengatasnamakan Menteri Keuangan, Anny juga mengeluarkan surat bernomor s-553/MK.2/2010 tertanggal 6 Desember 2010 perihal persetujuan kontrak tahun jamak Hambalang.

Tempo mengajukan permintaan wawancara khusus kepada Anny, tapi tak direspons. Dicegat di gedung Dewan Perwakilan Rakyat pada Rabu pekan lalu, Anny pun membungkam ketika ditanyai soal Sylvia Sholehah. Soal kontrak tahun jamak, dalam sejumlah kesempatan, Anny mengatakan terbitnya persetujuan sudah sesuai dengan prosedur.

Kamis pekan lalu, Tempo mendatangi kediaman Sylvia Sholehah di kompleks Monte Carlo, Pakuan, Bogor, untuk memunta konfirmasi. Menurut penghuni rumah, Sylvia sedang berada di Mataram, Nusa Tenggara Barat. Dihubungi lewat telepon seluler suaminya, Purnomo D. Rahardjo, Sylvia tak merespons. Purnomo menolak 
mengubungkan wartawan majalah ini dengan sang istri. "Sudahlah, Tempo memang nakal,"katanya.

Setelah disetujui, Kementerian Olahraga dan pemenang tender Hambalang, kongsi PT Adhi Karya dan PT Wijaya Karya, meneken kontrak proyek pada 10 Desember 2010. Delapan belas hari kemudian, kerja sama operasi Adhi-Wika mendapat pembayaran uang muka Rp 217 miliar. Dari situ, dana merembes ke mana-mana.

$* * *$

Setelah kontrak diteken, kelompok Sylvia diduga hanya menerima separuh yang diminta awal. Duit Rp 2,5 miliar dari Kementerian Olahraga itu diambil Widodo Wisnu Sayoko, keponakan Sylvia, di rumah Lisa Lukitawati pada awal 2011. Tapi, ketika diperiksa Badan Pemeriksa Keuangan untuk audit investigasi Hambalang tahap II, Lisa mengatakan yang mengambil uang itu Arif "Gundul".

Tentu saja, lelaki 30-an tahun itu tak bisa ditanya-tanya lagi. Ia meninggal pada akhir 2012 dan dimakamkan di Yogyakarta. Informasi tentang dia sangat minim. Sejumlah sumber hanya mengatakan ia berperawakan tinggi besar, berkepala plontos, dan anggota Partai Demokrat. Wododo sendiri tak mau menjawab ketika ditanyai wartawan setelah diperiksa Komisi Pemberantasan Korupsi pada akhir Mei lalu.

Uang untuk Sylvia cs bersumber dari dana Hambalang. Alurnya: KSO Adhi-Wika yang diketuai Teuku Bagus Muhammad Noor menyalurkan fee proyek kepada Machfud Suroso, Direktur PT Dutasari Citra Laras, subkontraktor Hambalang. Dari situ, uang mengalir ke Lisa Lukitawati. Menurut sejumlah sumber, Lisa berperan sebagai penjaga pintu air. Ia menyalurkan jatah Hambalang untuk Kementerian Olahraga dan banyak pihak lain, seperti Sylvia.

Lisa betul-betul aktif di Hambalang. Sejak awal, ia diduga pula ikut menentukan fee. Pada Juli 2010, pertemuan digelar di sebuah restoran di pusat belanja Plaza Senayan, Jakarta. Peserta lainnya adalah Kepala Biro Perencanaan Kementerian Olahraga Deddy Kusnidar, yang belakangan menjadi pejabat pembuat komitmen Hambalang, Muhammad Arifin dari Methapora, dan Teuku Bagus dari Adhi Karya.

Sebelum pertemuan di Plaza Senayan, menurut sejumlah informasi, orang-orang Kementerian meminta 16,5 persen dari nilai proyek, yang besarnya Rp 1,175 triliun. Untuk merundingkan angka final, digelarlah rapat di Plaza Senayan.

Menurut sumber, dalam rapat itu Lisa mengeluarkan catatan rencana jatah untuk pejabat di Kementerian. Para calon penerima diberi kode dari F I hingga F VI. F I kode untuk Menteri Pemuda dan Olahraga Andi Alfian Mallarangeng, sedangkan F II Wafid Muharam. Pada F I tertulis Rp 10,5 miliar dan F II Rp 7,8 miliar. Dalam catatan itu, total jatah untuk pejabat Kementerian Rp 32 miliar.

Teuku Bagus awalnya mencoba menawar. Tapi, setelah Lisa mengeluarkan catatan tadi, fee bukannya turun, jumlah yang diminta Kementerian Olahraga malah melonjak menjadi 18 persen. Pembayaran fee bakal mengikuti pencairan anggaran dari 
Kementerian. Sebagai kontrak tahun jamak, dana Hambalang turun bertahap. Tiap kali dana cair, 18 persennya disetorkan kembali ke Kementerian Olahraga. Tak ada pilihan, Adhi Karya menyetujui.

Setelah KSO Adhi-Wika menjadi pemenang tender dan mendapat uang muka proyek, Lisa mendatangi Teuku Bagus di kantornya menagih besel yang dijanjikan. Kejadiannya awal 2011. Teuku Bagus lalu mempersilakan Lisa menagihnya ke Machfud Suroso, Direktur Dutasari.

Menurut sumber, tak lama setelah itu, Machfud mengantarkan uang ke rumah Lisa di perumahan Pondok Indah, Jakarta. Jumlah pastinya belum jelas, tapi ditaksir Rp 5 miliar. Sekali itu Machfud mengantarkan uang ke Lisa. Selebihnya, duit diantarkan anak buah Machfud berulang kali.

Total uang yang diserahkan Teuku Bagus lewat Machfud ke Lisa terekam dalam catatan pengeluaran KSO Adhi-Wika. Menurut sumber, jumlah yang disalurkan lewat Machfud mencapai Rp 44 miliar. Dari KSO, dana dikemas sebagai pembayaran subkontrak pekerjaan subkontrak pekerjaan mekanikal-elektronikal oleh Dutasari.

Pengeluaran KSO Adhi-Wika untuk besel setelah kontrak diteken ditaksir mencapai Rp 70 miliar. Itu sudah termasuk yang disalurkan lewat Machfud Suroso. Ditambah pengeluaran PT Adhi Karya sebelum kontrak diteken-karena KSO ada setelah 10 Desember 2010-jumlah duit yang dirogoh dari brankas sekitar Rp 80 miliar. Adhi Karya rupanya menebar mahar lebih jauh sebelum proyek dilaksanakan.

Ketika proyek masih dalam tahap perencanaan pada September 2009, Adhi Karya sudah mengeluarkan Rp 5 miliar. Duit itu diduga disetorkan kepada Wafid lewat pengusaha Paul Nelwan dan untuk mengganti pengeluaran Machfud Suroso sebesar Rp 3 miliar. Nama Wafid tercatat lagi dalam pembukuan Adhi Karya. Pada April 2010, dia ditulis menerima Rp 1,1 miliar. Enam bulan kemudian, ia ditulis dua kali menerima Rp 2 miliar lewat Paul Nelwan dan Poniran, asisten Wafid.

Paul Nelwan menyangkal pernah menjadi perantara uang dari Adhi Karya kepada Wafid. Menurut dia, sekali-sekalinya ia menerima uang dari Adhi Karya kira-kira pada Januari 2010. Ia diutus Wafid meminjam uang kepada Adhi Karya untuk keperluan Kementerian Olahraga. "Untuk memberangkatkan atlet ke luar negeri," ujarnya.

Lisa Lukitawati lagi-lagi menggelengkan kepala ketika ditanyai soal peran dia dalam menegosiasikan fee dan menyalurkan uang. "Saya serahkan semuanya pada proses penyidikan yang ada di KPK," katanya.

Wafid Muharam belum bisa ditemui setelah menghuni Lembaga emasyarakatan Sukamiskin, Bandung. Melalui orang dekatnya, Tempo sudah menyampaikan permintaan wawancara. Tapi, kata dia, Wafid belum bisa ditemui karena sedang sakit. Erman Umar, pengacara Wafid dalam kasus suap Wisma Atlet SEA Games XXVI Palembang, mengatakan tak pernah diceritai kliennya soal lalu lintas fulus tadi. 
Bantahan juga datang dari Machfud Suroso. Menurut Machfud, ia tak pernah menyalurkan uang Hambalang kepada sejumlah orang, termasuk Lisa Lukitawati. Ia pun mengklaim tak pernah diminta Teuku Bagus menjadi perantara duit. "Kalaupun ada yang bilang, itu fitnah. Ayo, saya siap dikonfrontasi,"ujarnya Kamis pekan lalu.

Titik terang justru terlihat dari pengakuan Teuku Bagus lewat pengacaranya, Haryo Budi Wibowo. Menurut Haryo, betul ada pengeluaran dari Adhi Karya sebelum 10 Desember 2010 sebesar Rp 8-10 miliar. Adhi mengeluarkan uang karena ada permintaan dari Kementerian Olahraga melalui seorang pengusaha. "Kami berikan kepada swasta, bukan Kemenpora," katanya.

Ia juga tak memungkiri ada pertemuan dengan Lisa Lukitawati dan kawan-kawan yang membahas fee 18 persen. Seusai pertemuan, kata Haryo, Teuku Bagus marahmarah karena merasa diperas. Karena itu, kliennya tak menepati janji untuk membayar fee proyek. "Tak ada pemberian uang setelah kontrak diteken."

Dibantah dari segala penjuru, Ketua Komisi Pemberantasan Korupsi Abraham Samad yakin tabir yang merungkup kasus Hambalang segera tersingkap. "Hanya menunggu waktu." (Anton Septian, Nur Alfiyah, Rusman Paraqbueq)

\section{Dari Hambalang Mengalir Jauh}

\section{Lini Masa}

Berdiri di atas tanah seluas 31,2 hektare di gigir Bukit Hambalang, Bogor, proyek ini dimaksudkan untuk menggantikan pusat pendidikan dan pelatihan olahraga Ragunan. Direncanakan sejak 2004, proyek tersendatsendat. Hambalang kembali dipacu setelah Adi Alfian Mallarangeng menjabat Menteri Pemuda dan Olahraga. Berikut lini masa kasus ini:

\section{Pada tahun 2009}

Agustus-September

Anggaran proyek mulai dihitung. Bujet totalnya Rp 2,27 triliun. Rinciannya, biaya konstruksi Rp 1,175 triliun dan sisanya anggaran peralatan olahraga. Pada tanggal 22 Oktober Kabinet Indonesia Bersatu II dilantik. Andi Mallarangeng ditunjuk menjadi Menteri Pemuda dan Olahraga.

\section{Pada tahun 2010}

20 Januari Sertifikat Hambalang terbit. Tanggal 21-23 Mei Kongres Partai Demokrat di Bandung. Pada tanggal 28 Juni Sekretaris Kementerian Pemuda dan Olahraga Wafid Muharam mengajukan Hambalang sebagai kontrak tahun jamak kepada Kementerian Keuangan. Masih di bulan Juni Pertemuan di Hotel Wisma Atlet Century, Senayan, untuk membicarakan kontrak tahun jamak. Pada bulan Juli Pertemuan di Plaza Senayan untuk membicarakan fee Hambalang. Angkanya disepakati 18 persen. Pada tanggal 13 JuliDirektur Jenderal Anggaran Anny Ratnawati menjawab surat Wafid bahwa ia harus melengkapi data pendukung dari Kementerian Pekerjaan Umum. Pada tanggal 23 JuliWafid menyurati Kementerian PU untuk meminta rekomendasi kelayakan kontrak tahun jamak.Pada tanggal 18 Agustus Lelang konstruksi Hambalang dibuka. Pada tanggal 22 Oktober Direktur Penataan Bangunan dan Lahan Kementerian PU memberikan rekomendasi. - Wafid menyurati Kementerian Keuangan dengan 
melampirkan rekomendasi Kementerian PU. Pada tanggal 16 November Wafid meminta dispensasi revisi rencana kerja dan anggaran Kementerian Olahraga ke Kementerian Keuangan. Revisi paling lambat diajukan 15 Oktober. Pada tanggal 22 November Kementerian Olahraga meminta analisis komponen biaya dari Kementerian PU. Surat Wafid tertanggal 16 November sampai ke meja Anny Ratnawati, yang selanjutkan didisposisikan ke bawahannya. Pada tanggal 23 November Kementerian PU memberikan dokumen yang diminta Kementerian Olahraga, yang lalu diserahkan lagi ke Kementerian Keuangan pada hari yang sama. Pada tanggal 24 November KSO Adhi-Wika ditetapkan sebagai pemenang proyek. Pada tanggal 29 November Direktur Anggaran II Kementerian Keuangan menyampaikan nota dinas hasil penelaahan anggota stafnya kepada Anny Ratnawati bahwa dispensasi yang diminta Wafid bisa disetujui. Anny Ratnawati menyampaikan nota dinas persetujuan kontrak tahun jamak kepada Menteri Keuangan Agus Martowardojo. Pada tanggal 1 Desember Agus Martowardojo memberikan disposisi kepada Anny, dengan perintah, "Selesaikan." Pada tanggal 6 Desember Anny menerbitkan persetujuan kontrak tahun jamak Hambalang. Pada tanggal 10 Desember Kontrak proyek diteken pejabat pembuat komitmen dari Kementerian Olahraga, Deddy Kusnidar, dan Ketua KSO Adhi-Wika yang juga Kepala Divisi Konstruksi I PT Adhi Karya, Teuku Bagus Muhammad Noor. Pada tanggal 14 Desember PT Dutasari Citra Laras milik Machfud Suroso mendapat subkontrak dari KSO Adhi-Wika. Pada tanggal 28 Desember:

- $\quad$ KSO Adhi-Wika menerima pembayaran uang muka Rp 217 miliar.

- $\quad$ Transfer Rp 13,3 miliar dari KSO ke PT Dutasari.

- $\quad$ Transfer Rp 12,39 miliar dari KSO ke Adhi Karya.

- $\quad$ Transfer Rp 6,92 miliar dari KSO ke PT Wijaya Karya.

Pada tanggal 29 Desember

- $\quad$ Transfer Rp 25 miliar dari KSO ke Dutasari.

- $\quad$ Transfer Rp 70 miliar dari KSO ke Adhi Karya.

- $\quad$ Transfer Rp 30 miliar dari KSO ke Wijaya Karya.

\section{Pada tahun 2011}

Pada tanggal 11 Januari Transfer Rp 10 miliar dari KSO ke Dutasari.Pada tanggal 19 Januari Transfer Rp 6,5 miliar dari KSO ke Dutasari. Pada tanggal 25 Januari Transfer Rp 2 miliar dari KSO ke Dutasari. Pada tanggal 26 Januari Transfer Rp 6,5 miliar dari KSO ke Dutasari. Pada bulan Februari-Desember:

- $\quad$ Adhi Karya mengembalikan Rp 82,3 miliar ke KSO Adhi-Wika.

- $\quad$ Wijaya Karya mengembalikan Rp 36,92 miliar ke KSO Adhi-Wika.

Pada bulan Juni Teuku Bagus diangkat sebagai Direktur Operasional I Adhi Karya.

\section{Lini Suap}

Untuk mendapatkan proyek Hambalang, PT Adhi Karya harus merogoh brankas dalamdalam. Pengeluaran itu ditebar sejak proyek dirancang hingga setelah kontrak itu diteken pada 10 Desember 2010. Total yang sudah dikeluarkan sekitar Rp 80 miliar. Rinciannya, Rp 12,31 miliar sebelum kontrak dan sekitar Rp 70 miliar setelah
KSO Adhi-Wika resmi menggarap Hambalang. Angka ini sebenarnya lebih kecil daripada fee yang disepakati sebesar 18 persen dari total nilai proyek. Pengeluaran PT Adhi Karya sebelum kontrak: Rp 12,31 miliar

\section{Perempuan dari Lingkaran Dalam}

KPK menelisik peran Sylvia Sholehah dalam perkara korupsi Hambalang. Disebut- 
Pada tahun 2009

Pada tanggal 8 September 2009 Rp 1 miliar Wafid Muharam lewat Paul Nelwan. Pada tanggal 13 September 2009 Rp 3 miliar Machfud Suroso, untuk mengganti uang yang telah ia serahkan kepada Wafid. Pada tanggal 14 September 2009 Rp 1 miliar Wafid lewat Paul Nelwan.

\section{Pada tahun 2010}

Pada bulan Maret 2010 Rp 500 juta Adhyrusman Dault, adik Adhyaksa Dault, jasa mengurus sertifikat Hambalang. Pada bulan April 2010 Rp 1,15 miliar Wafid lewat Paul Nelwan. Pada bulan Oktober 2010 Rp 2 miliar + Rp 2 miliar Wafid lewat Poniran. Dengan catatan bahwa Hingga Juli 2012, KSO Adhi-Wika telah menerima Rp 514 miliar. Sisa anggaran dibintangi Dewan Perwakilan Rakyat setelah kasus Hambalang meruyak. Setelah kontrak diteken pada 10 Desember 2010, pengeluaran bersumber dari brankas KSO Adhi-Wika. Pengeluaran total: Sekitar Rp 70 miliar.

\section{Pada tahun 2011}

Awal 2011 Rp 44 miliar diserahkan secara bertahap $\square$ PT Dutasari/Machfud Suroso untuk Kementerian Olahraga. Dari situ, ada yang disalurkan lewat Lisa Lukitawati. Contohnya: Machfud menyerahkan sekitar Rp 5 miliar di rumah Lisa pada Januari. Pada bulan Januari 2011 Rp 2,5 miliar Lisa Lukitawati untuk Sylvia Sholehah lewat Arif dan Widodo Wisnu Sayoko. Masih di awal 2011Rp 8 miliar Sutisno untuk mengurus pengaktifan kembali proyek tol Bekasi-Cawang-Kampung Melayu. Pada bulan Juni 2011 Rp 1,7 miliar Untuk suksesi direksi PT Adhi Karya, yang memilih Teuku Bagus sebagai Direktur Operasional.

sebut dekat dengan keluarga Presiden. Tak sulit bagi seorang alumnus Akademi Angkatan Bersenjata Republik Indonesia 1973 mengenali foto perempuan berkerudung hitam yang separuh mukaya ditutup itu. "Itu istri Purnomo, perwira kepolisian seangkatan saya,"katanya pekan lalu, ketika Tempo menunjukkan foto perempuan yang sedang menghindari pertanyaan wartawan setelah diperiksa Komisi Pemberantasan Korupsi akhir Mei lalu.

Sylvia Sholehah-begitu nama perempuan itu tertera dalam daftar pemeriksaan saksi pada agenda harian komisi anti-korupsi-memang populer dengan sapaan "Ibu Pur". Ia dimintai keterangan dalam perkara korupsi dana proyek sarana olahraga terpadu Hambalang, Bogor. Ketika keluar dari ruang gedung KPK pada pukul 20.40 , ia sama sekali tak menjawab pertanyaan. Ia terus menutup mulutnya dengan sapu tangan, dan pergi menggunakan taksi.

Pada hari yang sama, KPK juga meminta keterangan Widodo Wisnu Sayoko. Seusai pemeriksaan, ia berlari menerobos kepungan wartawan. Ia berusaha mengelak, dan berkata, "Bukan, saya hanya mengantar Ibu." Melewati jembatan penyeberangan di Jalan Rasuna Said, Jakarta Selatan, tepat di depan gedung KPK, lelaki itu pergi menggunakan ojek. Juru bicara komisi antikorupsi, Johan Budi S.P., menyatakan Sylvia dan Widodo "berasal dari swasta".

Toh, menurut beberapa sumber, Sylvia dan Widodo bukan saksi biasa. Mereka berperan banyak dalam perkara korupsi yang mengantarkan Menteri Pemuda dan Olahraga Andi Mallarangeng dan mantan Ketua Umum Partai Demokrat Anas Urbaningrum menjadi tersangka itu. "Mereka orang Cikeas,"ujar seorang tokoh yang mengetahui perkara ini, merujuk pada kediaman pribadi Presiden Susilo Bambang Yudhoyono di Puri Cikeas, Bogor.

Berbekal keterangan alumnus Akabri 1973 tadi, Tempo mengecek daftar alumnus 
Akademi Kepolisian pada tahun yang sama. Di situ tercatat Purnomo D. Rahardjo, yang pensiun pada 2005. Dalam kolom keluarga daftar itu, klop, istrinya bernama Sylvia Sholehah. Tertera pula alamat dan nomor telepon rumah mereka.

Menurut informasi lain dari temanteman angkatannya, Purnomo kemudian banyak membantu keluarga Yudhoyono-juga alumnus Akabri 1973. Koleganya mengetahui Purnomo berperan sebagai "kepala urusan rumah tangga" kediaman Yudhoyono. Bersama istrinya, ia mengatur berbagai keperluan sehari-hari keluarga Cikeas. "Dari urusan dapur sampai mengatur taman,"katanya.

Sylvia juga sering tampil ke permukaan. Ia terlihat berada dalam rombongan Ibu Negara, Ani Yudhoyono, ketika menghadiri sejumlah kegiatan. Di antaranya pada peringatan Hari Olahraga Nasional di gedung Tennis Indoor Senayan, Gelora Bung Karno, pada September 2010.

Ketika Ani Yudhoyono membuka pameran "Pasar Tenun" di pusat belanja Senayan City, Jakarta Selatan, Sylvia alias Ibu Pur terlihat ada di barisan pertama rombongan. Seseorang yang hadir ketika itu menyaksikan dia juga berjalan tepat di belakang Ibu Negara. "Saat duduk, dia sederet dengan para menteri,"ujarnya. Bukan kebetulan jika banyak orang berusaha mendekati mereka agar bisa menembus lingkaran dalam Cikeas. Purnomo dan Sylviakemudianjuga dipakai buat melobi Ani Yudhoyono, misalnya, untuk mengundangnya hadir pada suatu acara. Mereka pun bergaul dengan kalangan pebisnis. "Mereka biasa datang memenuhi undangan makan malam dari satu pengusaha ke pengusaha lain,"kata seorang pengusaha.

"Sidik jari" Sylvia tertinggal dalam proyek pembangunan sarana olahraga terpadu Hambalang. Menurut seorang narasumber, ia beberapa kali berkunjung ke ruang kerja Sekretaris Kementerian Pemuda dan Olahraga Wafid Muharam dan Kepala Biro Perencanaan Deddy Kusnidar.

Mengetahui nama Sylvia, sejumlah pengusaha berusaha mendekati dia. Untuk keperluan ini, ia memiliki dua orang yang bisa diandalkan, yaitu Widodo Wisnu Sayoko dan seorang pria yang biasa dipanggil Arif Gundul. Pejabat-pejabat Kementerian Pemuda dan Olahraga pun berusaha dekat-dekat dengan Sylvia, termasuk Wafid Muharam, yang kini menjalani masa hukuman dalam perkara suap Wisma Atlet SEA Games XXVI, Palembang.

Seorang terpidana perkara korupsi di Kementerian Pemuda dan Olahraga mengatakan Sylvia dipakai Wafid ketika menolak permintaan utusan Muhammad Nazaruddin, yang menyampaikan keinginan menggarap proyek Hambalang. Nazaruddin, ketika itu masih menjadi Bendahara Umum Partai Golkar, menagih Wafid karena merasa berjasa mengamankan anggaran proyek di Dewan Perwakilan Rakyat. "Wafid mengatakan proyek Hambalang sudah diminta oleh utusan Cikeas bernama Ibu Pur,"ujarnya.

Nazaruddin saat itu tidak bisa berbuat apa-apa. Dia hanya menagih balik uang senilai Rp 9 miliar kepada Wafid. Belakangan, proyek pengadaan sport center senilai ratusan miliaran rupiah memang digarap perusahaan yang direkomendasikan Ibu Pur. Wafid, yang kini mendekam di Lembaga Permasyarakatan Sukamiskin, Bandung, menolak menjawab pertanyaan Tempo.

Seorang saksi kunci perkara Hambalang mengatasnamakan nama Ibu Pur sudah lama muncul dalam pemeriksaan, bahkan sejak penyelidikan. Dia mengaku berkali-kali ditanyai penyidik KPK dan auditor Badan Pemeriksa Keuangan. "Mereka menanyakan apa kenal Bu Pur,"katanya. "Saya yakin pertanyaan serupa ditanyakan ke saksi-saksi yang lain."

Anggota staf khusus Presiden, Heru Lelono, mengatakan tidak mengenal Purnomo dan Ibu Pur. "Disebut kerabat presiden, kerabat dari mana?"ujarnya. Adapun Sylvia tidak bisa dimintai komentar. Keluarga di rumahnya menyatakan ia dan Purnomo pergi ke Mataram, Nusa Tenggara Barat. Purnomo, yang dikontak lewat telepon seluler, menolak mengubungkan Tempo dengan istrinya. Dia menuding media massa mencari-cari kesalahan keluarganya. 
"Sudahlah, Tempo memang nakal,"katanya Nur Alfiyah, Ananda Badudu, Febriana Firdaus). (Setri Yasra, Anton Septian, Rusman Paraqbueq,

Lisa Lukitawati Isa: Orang Bilang Saya Tahu Banyak

Perempuan 43 tahun ini malang-melintang di Kementerian Pemuda dan Olahraga sejak 200. Semula Lisa Lukitawati Isa diangkat Sekretaris Kementerian Wafid Muharam sebagai tenaga asistensi teknis peralatan kesehatan. Ketika proyek Hambalang mulai dirancang, Lisa ditunjuk sebagai anggota tim perencana-dengan surat keputusan resmi dari Wafid.

Walau begitu, Lisa, yang juga pengusaha peralatan olahraga, kerap bertugas di wilayah yang tidak sesuai dengan deskripsi pekerjaannya. Ia diduga ikut menentukan fee proyek Hambalang hingga menyalurkan uang. "Orang bisa berkata apa saja demi keuntungan masing-masing,"kata Lisa ketika ditemui Anton Septian dari Tempo di kantornya di bilangan Pondok Pinang, Jakarta, Kamis pekan lalu.

Anda kenal dengan Sylvia Sholehah alias Ibu Pur?

Itu Pak Wafid Muharam yang kenal.

Kenal dengan dua orang dekat Sylvia, Widodo Wisnu Sayoko dan Arif?

Tanya Pak Wafid dan Pak Deddy Kusdinar, deh.

Ada informasi bahwa mereka membantu mengurus persetujuan kontrak multiyear?

(Menggelengkan kepala).

Anda menjadi perantara pemberian uang dari KSO Adhi-Wika ke sejumlah pihak, termasuk kepada Sylvia dan pejabat di Kementerian Pemuda dan Olahraga?

(Menggelengkan kepala).

Bukankah dulu Anda yang menyerahkan uang kepada Mindo Rosalina Manulang? Ada informasi uang itu juga berasal dari fee Hambalang?

Kalau itu, tanyakan ke KPK, deh. (Lisa pernah mengaku menyerahkan uang kepada Rosa atas perintah Wafid Muharam pada awal Januari 2011).

Informasi yang kami peroleh, Ketua KSO Adhi-Wika Teuku Bagus Muhammad Noor tal secara langsung menyerahkan uang ke Kementerian Pemuda, tapi melalui sejumlah orang, termasuk Anda...

Saya tak mau memberikan komentar pada sesuatu yang prosesnya masih berjalan.

Betulkah Anda ikut menentukan besaran fee proyek Hambalang yang 18 persen itu?

Orang bisa berkata apa saja demi keuntungan masing-masing. Saya serahkan semuanya pada proses penyidikan yang ada di KPK. 


\section{Bukan hanya satu sumber yang menyebut peran Anda dalam Hambalang....} Orang bilang saya tahu banyak, orang boleh berkata apa saja. Tapi saya tak mau melakukan hal yang sama seperti mereka.

\section{Bagaimana kasus Hambalang versi Anda?}

Saya sudah mengatakan sebenar-benarnya kepada penyidik.

\section{Dari tadi jawaban Anda tidak jelas. Kali ini cukup jawab benar atau tidak Anda ikut menentukan fee Hambalang hingga menyalurkan uang KSO Adhi-Wika ke sejumlah orang?}

Percuma saya menjawab benar atau tidak.

\section{Ketika ditanya penyidik, Anda memberikan jawaban mengambang juga?}

Saya menyampaikan apa yang saya tahu, tapi tak mau membuka aib orang lain. Bila saya sudah berada di satu jalan, saya akan tetap berada di situ walaupun hal itu akan menjatuhkan saya (Tempo/Seto Wardhana)

Indonesia telah memiliki UndangUndang (UU) No. 14 Tahun 2008 tentang Keterbukaan Informasi Publik. Salah satu prinsip yang dipakai dalam penyusunan UU ini adalah "Menegakkan Pemerintah Yang Transparan". Secara operasional, UU ini mendorong lembaga-lembaga pemerintah untuk menegakkan pemerintahan secara transparan. Di samping itu, UU ini juga memberitahukan hak-hak masyarakat dalam menegakkan budaya transparansi dalam pemerintahan. Salah satu hak itu adalah mengetahui persoalan yang terjadi terjadi dalam pemerintahan. Dengan demikian, UU ini menegaskan bahwa masyarakat punya hak mengetahui.

Secara spesifik, UU No. 14 Tahun 2008 menegaskan hak tersebut dalam Pasal 3 butir a. menjamin hak mengetahui:(i) rencana pembuatan kebijakan publik, (ii) program kebijakan publik, (iii) proses pengambilan keputusan publik, dan (iv) serta alasan pengambilan suatu keputusan publik.

Pengakuan terhadap hak mengetahui ini juga dijamin oleh Undang-Undang No. 39/1999 tentang Hak Asasi Manusia. Pasal 14 UndangUndang itu menyebutkan:(1) Setiap orang berhak untuk berkomunikasi dan memperoleh informasi yang diperlukan untuk mengembangkan pribadi dan lingkungan sosialnya, dan (2) Setiap orang berhak untuk mencari, memperoleh, memiliki, menyimpan, mengolah, dan menyampaikan informasi dengan menggunakan segala jenis sarana yang tersedia.

Persoalannya lantas, khalayak harus mengetahui apa? Mengetahui persoalanpersoalan publik yang terjadi di sekitar mereka dan yang berhubungan dengan kehidupan mereka. Sampai di sini muncul pertanyaan, siapa yang harus melayani hak mengetahui khalayak tersebut? Jawabannya, tegas. Media pers.

Kenyataan ini bisa dilihat pada UndangUndang No. 40/1999 tentang Pers. Pasal 6 UU itu berbunyi: "Pers Nasional melaksanakan peranannya sebagai berikut: a. Memenuhi hak masyarakat untuk mengetahui". Ini menunjukkan bahwa media pers akan selalu berusaha memenuhi hak khalayak untuk mengetahui.

UUNo.40/1999 tergolong regulasimedia. Regulasi media, seperti disebut Isang Gonarsyah (dalam Mau, 2013:2) bersifat membatasi perilaku media. Ia menjaga keberadaan dirinya ketika berinteraksi dengan khalayak. Dengan begitu, kepatuhan media pers pada regulasi media akan memelihara kredibilitas dan reputasi media pers bersangkutan.

Sesungguhnya regulasi media sarat dengan kepentingan politik. Regulasi media bisa menguntungkan satu pihak dan merugikan pihak 
lain. Lebih dari itu, regulasi media bisa menjadi cermin sebuah demokrasi. Namun, di Indonesia sekarang, seperti ditulis Amir Effendi Siregar (2010:9), demokratisasi pers cenderung luntur karena banyak pemberitaan yang tidak berimbang dan banyak pula pemberitaan yang mengandung unsur kepentingan politik. Akibatnya, berita yang disiarkan media pers tidak adil (fair) lagi.

Dalam pemberitaan, keadilan merupakan salah satu nilai yang tidak boleh dilupakan. Adil di sini, hendaklah dilihat dalam relasi media pers dan khalayak. Artinya, adil selalu berkaitan dengan perlakuan media pers terhadap khalayak. Maka dari itu, sebuah media pers akan disebut adil kalau ia memberikan apa saja yang dibutuhkan khalayak.

Dalam konteks berita korupsi, media pers masih perlu meningkatkan pelayanannya kepada khalayak. Media pers perlu meningkatkan jumlah informasi yang harus diberikan kepada khalayak. Media pers perlu mengorientasikan beritanya agar khalayak benar-benar well informed. Mereka tidak bertanya-tanya lagi tentang informasi yang sampai kepada mereka.

Sejalan dengan itu, media pers juga tidak perlu mengejar popularitas. Media pers tidak perlu berusaha menjadi yang terdepan dalam segala pemberitaan. Sebab, khalayak akan selalu menghargai media pers yang berusaha melayani hak mengetahui mereka dengan sebaik-baiknya. Khalayak akan menyanjung media pers yang punya i'tikad baik tentang diri mereka. Mereka, bahkan, akan memuji media pers yang tulus mengutamakan kepentingan mereka.

Secara praktis, media yang mengejar popularitas disebut media yang menjalankan politik pencitraan. Politik pencitraan akan menghasilkan citra. Citra, seperti ditulis Yasraf Amir Piliang (Dalam Muhammad, 2012:87), merupakan bentuk manipulasi realitas untuk kepentingan tertentu, dan pada tingkat yang ekstrim tercerabut dari dunia realitas. Dengan demikian, media pers yang melakukan politik pencitraan sangat berbahaya bagi khalayak.

Bertolak dari kerangka pemikiran di atas, penelitian ini dimaksudkan untuk melihat konsep keadilan dan hasrat popularitas dalam laporan utama MBM Tempo dan berita utama SKH Kompas tentang berita korupsi. Kedua konsep ini akan dilihat pada: (i) kelengkapan fakta berita yang menjawab pertanyaan What, Who, When, Where, Why dan How $(5 \mathrm{~W}+1 \mathrm{H})$, dan (ii) kandungan fakta yang terdapat dalam berita yang mengejawantahkan keadilan atau hasrat popularitas.

\section{Berita Diyakini Hanya Perantara: KPK Tetapkan Mario Bernardo dan DjodiSupratman sebagai Tersangka}

Berita ini tentang penetapan Mario C. Bernardo dan Djodi Supratman sebagai tersangka oleh Komisi Pemberantasan Korupsi (KPK). Ini yang menjadi fokus berita atau fakta yang menjawab pertanyaan What.

Siapa yang menetapkan? KPK seperti disampaikan oleh juru bicara KPK. K a p a $n$ ditetapkan? Pada Jumat, 27 Juli 2013, sehari setelah penangkapan. Dimana ditetapkan? Di Jakarta, di Kantor KPK. Mengapa ditetapkan? Karena memenuhi syarat ditetapkan sebagai tersangka. Yaitu memiliki alat bukti diduga melanggar Pasal 5 Ayat 1 Huruf a atau Pasal 13 Undang-Undang Nomor 31 Tahun 1999 sebagaimana diubah dengan UU No 20/2001 tentang Pemberantasan Tindak Pidana Korupsi juncto Pasal 55 Ayat 1 Kesatu KUHP. "Kasusnya adalah dugaan tindak pidana korupsi dalam kaitan memberi atau menjanjikan kepada pegawai negeri atau penyelenggara negara, terkait dengan pengurusan kasasi tindak pidana penipuan atas nama terdakwa HWO (Hutomo Wijaya Ongowarsito) di MA," ujar Johan. Bagaimana ditetapkan? Ditetapkan dengan keyakinan bahwa mereka menjadi perantara yang mengurus perkara penipuan dengan terdakwa Hutomo Wijaya Ongowarsito, yang kini tengah kasasi di MA.

Data di atas memperlihatkan bahwa semua fakta tentang fokus berita terpenuhi. Artinya, berita ini merupakan berita yang lengkap. Persoalannya adalah, apakah berita ini hanya mencari popularitas atau benar-benar 
merupakan berita yang adil? Kriteria berita yang adil menurut Djawoto (1950:75), antara lain: (i) berita tidak memvonis terduga bersalah, (ii) beritanya utuh, tidak separoh-separoh, dan (iii) tidak dibubuhi komentar wartawan. Menilik ketiga kriteria ini terhadap berita di atas, jelas berita ini adil. Sebab, berita ini memenuhi ketiga kriteria tersebut.

Namun, ketika berita tersebut menyebutkan nama lengkap terduga, ini menjadi sebuah tanda tanya. Mengapa begitu? Bukankah biasanya media pers hanya menyebutkan inisial namanya saja? Lalu, ketika berita tersebut menyebutkan nama firma hukum tempat terduga bekerja (Kantor Hotma Sitompoel) dan atasannya (Hotma Sitompoel), muncul lagi sebuah pertanyaan, apa relevansinya dengan fokus berita? Tidak heran keadaan ini akan menimbulkan spekulasi kalangan khalayak bahwa berita tersebut tidak sepenuhnya adil. Bukan mustahil pula mereka akan menilai bahwa SKH Kompas mencari popularitas.

\section{Berita Kode "F" di Tahap Kedua Korupsi Hambalang:}

Berita ini melaporkan kisah kontrak jamak Kementerian Olahraga dan Pemuda untuk pembangunan konstruksi Hambalang dan anggaran peralatan untuk mengisi bangunan dengan jumlah biaya sebesar Rp 2, 57 triliun. Ini yang menjadi fokus berita dan menjawab pertanyaan What.

Siapa yang memutuskan kontrak jamak itu? Wafid Muharam, Sekretaris Menteri Olahraga dan Pemuda. Kapan diputuskan? Pada 6 Desember 2010 melalui sebuah surat persetujuan Wakil Menteri Keuangan Anny Ratnawati yang mengatasnamakan Menteri Keuangan. Surat itu bernomor s-553/MK.2/2010. Dimana diputuskan? Di Jakarta. Mengapa diputuskan? Karena Menteri Keuangan, Agus Martowardoyo sudah memberi persetujuan tentang kontrak tahun jamak Kementerian Olahraga dan Pemuda pada 1 Desember. Dalam disposisi itu, Menteri Keuangan memberikan disposisi kepada Anny Ratnawati untuk menyelesaikan permohonan kontrak tahun jamak Kementrian Olahraga dan Pemuda. Bagaimana perjalanan keputusan itu? Penuh dengan liku-liku suap dan penyalahgunaan wewenang untuk memperkaya diri sendiri dan menghabiskan uang negara. Kisah ini, bila dilihat dari Undang-Undang No. 20 Tahun 2011 tentang Tindak Pidana Korupsi, jelas-jelas merupakan tindak pidana korupsi. Karena di situ, ada orang yang memperkaya diri sendiri dengan merugikan negara. Ada pula orang yang menyuap pegawai negeri. Ada, bahkan, pejabat yang memanfaatkan kekuasaannya untuk memperkaya diri sendiri atau diri orang lain.

Data di atas menunjukkan bahwa semua fakta tentang fokus berita terpenuhi. Beritanya lengkap. Lalu, apakah berita tersebut adil atau ingin mencari popularitas? Menggunakan ketiga keriteria berita adil, terlihat bahwa berita tersebut adil. Namun, nama semua orang yang terlibat dalam kisah kontrak tahun jamak Kementerian Pemuda dan Olahraga ditulis secara lengkap, tidak hanya inisialnya. Dari penulisan seperti ini khalayak jadi punya persepsi negatif terhadap beberapa nama yang menerima uang panas. Tidak heran bila khalayak bertanya-tanya tentang motif penyebutan nama lengkap orang yang terlibat dalam kisah tersebut.

\section{Berita Dari Hambalang Mengalir Jauh:}

Berita, yang terdiri atas dua bagian ini, merupakan kronologis kisah kontrak tahun jamak Kementerian Olahraga dan Pemuda untuk konstruksi Hambalang dan peralatan untuk mengisi bangunannya. Satu bagian memaparkan tonggak waktu penting dalam kisah tersebut. Satu bagian lain memaparkan pihak-pihak yang menikmati uang suap yang diberikan PT Adhi Karya sebelum dan sesudah kontrak dilakukan. Jumlah uang suap tersebut mencapai Rp 82,31 milyar. Semuanya merupakan pemaparan yang lebih sistematis dari berita Kode " $F$ " di Tahap Kedua Korupsi Hambalang. Jadi, peneliti tidak bisa merinci fakta-fakta yang menjawab pertanyaan $5 \mathrm{~W}+1 \mathrm{H}$.

Namun berita ini menyebut dengan jelas nama lengkap penerima uang suap beserta 
tanggal penerimaannya. Lebih dari itu, berita ini juga memuat foto-foto mereka yang menerima uang. Sampai di sini, timbul pertanyaan tentang motif penyiaran berita seperti itu.

\section{Berita Perempuan Dari Dalam Lingkaran}

Berita ini merupakan profil seorang tokoh kunci dari disetujuinya kontrak tahun jamak Kementerian Olahraga dan Pemuda untuk proyek Hambalang dan peralatan untuk mengisi bangunannya. Perempuan itu bernama Sylvia Sholehah.

Siapa Sylvia sebenarnya? Dia merupakan istri Purnomo, pensiunan polisi yang lulus Akademi Angkatan Bersenjata Republik Indonesia (Akabri) tahun 1973. Suaminya seangkatan dengan Presiden SBY ketika di Akabri. Apa jabatan Sylvia? Dia merupakan orang dekat keluarga Presiden Susilo Bambang Yudhoyono (SBY). Suaminya merupakan "kepala urusan rumah tangga" kediaman SBY di Cikeas. Apa peran Sylvia dalam kasus Hambalang? Dia dipakai orang, termasuk Wafid Muharam, untuk mendekati Ani Yudhoyono agar bisa memperoleh proyek dari pemerintah. Dia pernah mendatangi ruangan Wafid Muharam dan Deddy Kusnidar (Kepala Biro Perencanaan Kementerian Pemuda dan Olahraga). Wafid Muharam sudah menjalani hukuman dalam perkara suap Wisma Atlet SEA Games XXVI, Palembang. Berapa Sylvia memperoleh uang suap dari proyek Hambalang? Rp 2,5 milyar. Uang itu diserahkan Lisa Lukitawati lewat Arif dan Widodo Wisnu Sayoko. Bagaimana tanggapan Sylvia mengenai tuduhan yang diajukan kepadanya? Sylvia tidak berkata apaapa. Dia sama sekali tidak merespons. Padahal waktu itu dia baru saja keluar dari Ruang Pemeriksaan KPK dan ditunggu oleh banyak wartawan.

Fakta di atas menunjukkan bahwa semua fakta penting tentang diri Sylvia Sholehah tersedia. Beritanya lengkap. Namun, apakah berita tersebut tergolong adil? Menggunakan kriteria yang digunakan di atas. Berita ini tergolong adil.

\section{Berita Lisa Lukitawati Isa: Orang Bilang Saya Tahu Banyak}

Berita ini merupakan hasil wawancara dengan Lisa Lukitawati Isa. Wawancara ini dimaksudkan untuk memperoleh informasi tentang informasi yang terdapat dalam berita Perempuan Dari Dalam Lingkaran, berita Kode " $F$ " di Tahap Kedua Korupsi Hambalang, dan berita Dari Hambalang Mengalir Jauh. Namun, berita ini ditulis dalam bentuk tanya-jawab. Dengan begitu, berita ini tidak termasuk berita yang dianalisis.

Lalu, apa yang bisa disimpulkan dari kenyataan-kenyataan di atas? Barangkali kita menyimpulkan beberapa hal, yakni, pertama, SKH Kompas memang menyiarkan berita utama Diyakini Hanya Perantara: KPK Tetapkan Mario Bernardo dan Djodi Supratman sebagai Tersangka secara adil. Namun, ia menyebutkan nama lengkap terduga. Padahal biasanya media pers hanya menyebutkan inisial nama saja. Kecuali itu, ia juga menyebutkan nama firma hukum tempat terduga bekerja (Kantor Hotma Sitompoel) dan atasannya (Hotma Sitompoel). Ini masih berbau mencari popularitas.

Kedua, MBM Tempo memang memberitakan laporan utamanya yang berjudul Perempuan Misterius Hambalang secara adil. Namun, seperti halnya SKH Kompas, MBM Tempo juga menulis nama terduga secara lengkap. Dalam keadaan begini, peneliti beranggapan bahwa MBM Tempo masih memiliki aroma mencari popularitas.

Sampai di sini, tentu muncul pertanyaan, apakah SKH Kompas dan MBM Tempo sudah melayani hak mengetahui yang dimiliki khalayak. Data di atas menunjukkan bahwa sesungguhnya SKH Kompas sudah melayani hak mengetahui yang dimiliki khalayaknya tentang fokus berita yang disiarkannya. MBM Tempo juga sudah melayani hak mengetahui yang dimiliki khalayaknya tentang fokus berita yang disiarkannya.

Kenyataan ini menimbulkan pertanyaan berikut, bagaimana pelayanan hak mengetahui 
yang dilakukan SKH Kompas dan MBM Tempo? Secara umum pelayanan itu sudah baik. Artinya, khalayak sudah memperoleh informasi yang lengkap tentang fokus berita yang disiarkan.

Lalu, apa makna data diatas dari perspektif kebudayaan? Menurut perspektif kebudayaan data tersebut bermakna bahwa SKH Kompas dan MBM Tempo ingin mengingatkan khalayak bahwa korupsi itu merusak bangsa, merugikan diri sendiri dan keluarga, serta membuat rakyat jadi miskin. Kedua media pers itu tidak ingin ada lagi korupsi di masa mendatang. Untuk itu, mereka bertungkus-lumus mengumpulkan dan mengolah informasi sehingga menjadi seperti apa yang disampaikannya.

\section{Simpulan}

Dalam sambutannya sebagai Presiden, untuk memperingati seperempat abad usia Serikat Penerbit Suratkabar (SPS), pada 8 Juli 1971, Soeharto mengatakan bahwa surat kabar merupakan salah satu kebutuhan manusia. Selanjutnya dia berkata:

Manusia makin ingin mengetahui keadaan sekitarnya, keadaan Tanah Air dan Bangsanya, malahan keadaan dunia. Kebutuhan itu, sebagian terbesardengan cepat dan luas-dapat diketahui dari suratkabar. Tentunya juga telah disadari oleh mereka yang bekerja di lingkungan persuratkabaran, bahwa suratkabar pun dapat mempengaruhi alam pikiran dan bahkan sikap dari masyarakat, dapat memberikan perasaan tenteram dan keyakinan terhadap hari depan; tetapi, dapat juga menimbulkan kegelisahan dan kegoncangan kepada masyarakat (Soeharto, 1971:9).

Kutipan di atas menunjukkan bahwa pada tahun 1971 saja, Presiden Indonesia ketika itu, Soeharto, sudah menekankan betapa perlunya media pers melayani hak mengetahui yang dimiliki khalayak. Kini, 42 tahun kemudian, seiring dengan kemajuan zaman, pelayanan hak mengetahui ini tentu saja semakin penting. Terpulang kepada media pers sekarang, apakah akan meningkatkan pelayanan hak mengetahui itu atau tidak. Hal yang jelas, sejarah akan mencatat apa yang sudah dilakukan media pers tentang pelayanan hak mengetahui tersebut.

Catatan itu akan semakin bermakna ketika dikonfirmasikan dengan hari hak mengetahui internasional (International Right to Know Day) yang diperingati setiap 28 September. Bukankah Indonesia sudah memperingati hari hak mengetahui internasional secara resmi sejak 28 September 2010?

\section{Daftar Pustaka}

Djawoto. 1950. Jurnalistik Dalam Praktek. Jakarta: Penerbit Pena (Penyiaran Penerbit Nasional).

Mau, Severinus. 2013. Jenis-Jenis Regulasi Media. Makalah UAS Etika dan Regulasi Media. Yogyakarta.

Muhammad, Husein. 2012. Sang Zahid: Mengarungi Sufisme Gus Dur. Yogyakarta: LKiS.

Siregar, Amir Effendi. 2010. Demokratisasi Komunikasi dan Media: Jangan Setengah Hati! Yogyakarta: PR2Media. Soeharto. 1971. Sambutan. Dalam Samawi dkk, Garis Besar Perkembangan Pers Indonesia. Jakarta: Serikat Penerbit Suratkabar Pusat.

Oetama, Jakob. 2009. "Demokrasi dan Kebudayaan". Dalam Bambang Widianto dan Iwan Meulia Pirous, Perspektif Budaya. Jakarta: Penerbit Buku Kompas.

Undang-Undang Republik Indonesia No. 39 Tahun 1999 tentang Hak Asasi Manusia. Undang-Undang Republik Indonesia No. 40 Tahun 1999 tentang Pers. Undang-Undang Republik Indonesia No. 14 Tahun 2008 tentang Keterbukaan Informasi Publik. Undang-UndangRepublikIndonesiaNo.20Tahun 2011 tentang Tindak Pidana Korupsi.

\section{Suratkabar, Majalah dan Jurnal}

Parlementaria, Jakarta, Edisi 103 Tahun 2013. Respons, Jakarta, 1 Juli 2007. 